\title{
A CRITICAL ANALYSIS OF THE INFLUENCE OF START-UP FACTORS IN SMALL BUSINESSES AND ENTREPRENEURIAL VENTURES IN SOUTH AFRICA
}

\author{
JJ Van Vuuren, University of Pretoria \& D Groenewald, University of Johannesburg, South Africa
}

\begin{abstract}
Purpose: This paper focuses on a critical analysis of the influence of start-up factors in small businesses and entrepreneurial ventures in Gauteng, a province in South Africa.

Problem investigated: Owing to the low economic growth, high unemployment, and an unsatisfactory level of poverty in South Africa, entrepreneurship becomes a critical solution for the starting and developing of small businesses. Although the South African Government are constantly improving in eliminating barriers to potential start-ups, South Africa's TEA is not up to standard if it wants to sustain economic growth rates that will create wealth for everybody. Various factors influence and play a role in the establishment and operation of small businesses and entrepreneurial ventures.
\end{abstract}

Design/methodology/approach: An ex-post facto, formal research design was used as respondents were requested to indicate on a four-point scale how important they deemed 37 items in a structured personal interview. A sample of 312 elements was included in the research. The data was analysed through a factor analysis and analysis of variance.

Findings: Four factors were identified that influence the start-up of small businesses and entrepreneurial ventures. They are: personal management and involvement; role models; effective time management; and support from partners and advisors. It is very clear that there is a definite difference in the needs and factors influencing: women and male entrepreneurs; the age of entrepreneurs and the stage of the business in its life cycle.

Value of research: By analysing the factors that influence start-up, it can make potential entrepreneurs aware of the importance of considering these factors in the start-up and growth of their businesses.

Conclusion: The findings of this research are in line with similar international research (Mazzarol et al., 1999 and Deakins \& Freel, 2003) on various aspects influencing the start-up of businesses. Although a lot of support, education and training are given in South Africa, policy makers and educational institutions should take note of the various differences in needs and make provision in their support and training for these differences. It is also recommended that existing small business owners and entrepreneurs must create their own support structure specifically when they move from the start-up stage to the new firm stage, as this is a stage where support and advice is much needed.

Key words and phrases: entrepreneurial ventures, entrepreneurs, small business, start-up

\section{INTRODUCTION}

The vital role small businesses and entrepreneurship play in stimulating economic activity, job creation, poverty alleviation and the general upliftment of living standards has been recognised both internationally and in South Africa. Owing to the low economic growth, high unemployment and an unsatisfactory level of poverty in South Africa, entrepreneurship becomes a critical solution for the starting and developing of small businesses.

The Global Entrepreneurship Monitor (GEM) gives an indication of a country's entrepreneurial intensity where the focus is specifically on the Total Early-Stage Entrepreneurial Activities (i.e. from 0 months to 3.5 years). The TEA index measures the percentage of individuals between the ages of 18 and 64 that are involved in starting new businesses. According to Maas and Herrington (2006:7), South Africa's TEA is not up to standard if it wants to sustain economic growth rates that will create wealth for everybody. "With a young population, more pressure will be exerted on existing businesses to create enough wealth for all. If the TEA activities are not improved quickly enough, the danger exists that the dependency level of existing businesses will become too much. South Africa's TEA rate declined from $5.4 \%$ in 2004 , to $5.1 \%$ in 2005 and slightly increased to $5.29 \%$ in 2006. 
The established firm rate (the percentage of adults who are owner-managers of businesses that have paid wages for more than 3.5 years) according to the 2005 GEM report, is $1.3 \%$. This figure is the lowest of the GEM countries sampled in 2005. With the exception of Mexico, South Africa's start-up businesses are least likely of all the eight developing countries sampled to mature to the new firm stage. This indicates a lower success rate of new ventures in South Africa by comparison with most other developing countries. Von Broembsen, Wood and Herrington (2005:20) state that the low overall ranking of the developing countries, with the exception of Brazil and Thailand, the chances of a business surviving beyond three and a half years in a developing country is generally lower than in a developed country. The prognosis of survival, and therefore of establishing sustainable businesses, in South Africa is particularly poor.

When the factors that draw people into small business are present in a country, the conditions will be positive for entrepreneurship to do well there. A variety of economic and non-economic, social and personal conditions needs to be present for entrepreneurship to grow - economic conditions include, for example, availability of capital, support from government, financial infrastructure and using new technologies; non-economic conditions include, for example, desire for personal achievement, desire for social contribution, opportunity to improve personal wealth and social status, research and development, good educational system and good infrastructure (Co, Groenewald, Mitchell, Nayager, Van Zyl, Visser, Train \& Emanual, 2006:25-26).

As other factors, by analysing the factors that influence the start-up of small businesses and entrepreneurial ventures it can make potential entrepreneurs aware of the importance of considering these factors in the start-up and growth of their businesses. Once these factors are identified it could be incorporated in the training and development programmes of South African secondary and tertiary curriculums.

This paper focuses on a critical analysis of the influence of start-up factors in small businesses and entrepreneurial ventures in South Africa. Firstly, the problem statement and research objectives are stated. Thereafter, a brief overview of the literature on factors influencing the start-up factors in small businesses and entrepreneurial ventures is given. Reference to some major research on South African small businesses is also stated. Next, the research methodology is described, followed by the findings and results of the research study. Lastly, some recommendations to potential entrepreneurs, policy makers and educational institutions are provided.

\section{PROBLEM STATEMENT}

Atherton (2003:2) stated that levels of start-up of new businesses have been identified, and are used, by policymakers and in policy studies as a measure of overall entrepreneurial activity and potential within economies. In broad terms, the logic is that new business start-ups produce new sources of wealth and innovation as these entrants seek out and create new business opportunities and activities. Raising levels of involvement in business start-up also increases the number of people directly involved in entrepreneurship and entrepreneurial endeavours.

According to Atherton (2003:3), many strategies that have been developed in order to stimulate more entrepreneurs and higher levels of business formation have focused on reducing the barriers to start-up, in particular those relating to regulation, and on generating a broad portfolio of subsidised and state-supported initiatives and institutions providing funding, services and assistance to starters of new businesses. However, there appears to be some recognition that the wider culture and broadly held social values influence individual's propensities to engage in starting their own business. In addition, there is a growing recognition that experiences, attitudes and events prior to new venture creation process affect individual propensities and tendencies to start-up. There are indicators, therefore, that a critical influence on the likelihood of or propensity for individuals to start a business is the personal experiences of the starter prior to engagement in new venture creation. Some studies indicate that individuals who have had previous experience of starting a business, or who come from a family with a tradition of owner-management and entrepreneurship, have a broadly higher likelihood of setting up their own business. There is also evidence that individuals are more likely to consider starting their own business if their immediate peer group contains, i.e. individuals who have established their own business, and recognise the value of entrepreneurship. 
Deakins and Freel (2003:224) indicate that every business start-up is a unique event; the circumstances that contribute to success are intangible and may be different for each individual entrepreneur. Thus careful recommendations must be made about the paths to success, because what may work for one entrepreneur may not work for another. Intervention and support still have a role in the start-up process.

The South African Government recognises the importance of developing a strong SMME (Small, medium and micro-enterprises) sector and is consistently improving on eliminating barriers to potential start-ups.

Yet, the TEA rate of South Africa is 5, 29\%, as indicated in the Global Entrepreneurship Monitor and relatively low in comparison with other developing countries.

Van Eeden, Viviers and Venter (2003:13) indicate that the estimated failure rate of SMMEs is between $70 \%$ and $80 \%$ and millions of Rands are being lost on business ventures because of avoidable mistakes and problems. Streek (2001) in Van Eeden et al. (2003:13) indicated that 117 246 small businesses failed during the period 1997 to 2000 and this resulted in a lost of R68 million.

An awareness of possible future problems facing entrepreneurs will enable them to be forewarned, and proactive in their decision-making. Starting a business is risky at best, but the chances of success are enhanced if the problems anticipated are understood and addressed prior to the business starting or the problem arising.

Walker and Webster (2007:123) indicate that the reason why people start a business has been one of the most extensively researched topics in the field of small business management. Together with this, a wide range of research on barriers to start-up and growing small businesses as well as success factors has also been done internationally. Most of the research done in South Africa does not focus on the influence of various start-up factors but rather on the barriers to start-up factors.

Determining the influence of start-up factors as experienced by already successful small business owners and entrepreneurs in South Africa, it could serve as a contribution to an already existing body of knowledge as how to guide and support start-ups to be successful. This research therefore addresses, in spite of existent knowledge of start-ups and small businesses contribution to the economy and the availability of a considerable number of programmes, funding as well as endless organisations oriented to assist SMME's, on an analyses of the influence of start-up factors of successful small business owners and entrepreneurs in South Africa.

\section{RESEARCH OBJECTIVES}

The primary objective of this research is to conduct a critical analysis of the influence of start-up factors in small businesses and entrepreneurial ventures in Gauteng, a province in South Africa.

In order to achieve the primary objective, the secondary objectives are formulated. The secondary objectives are to:

- identify the start-up factors that influence small businesses and entrepreneurial ventures in the Gauteng province, a province in South Africa; and

- make recommendations to the existing body of knowledge on the start-up of small businesses in South Africa, which could be considered by policy makers and education and training institutions.

\section{HYPOTHESES}

Ho1: There is no significant difference between gender groups regarding personal management and involvement of start-up entrepreneurs

Ho 2: There is no significant difference between the age groups of businesses regarding personal Management and involvement

Ho 3: There is no significant difference between the different age groups of entrepreneurs regarding their effective time management at start-up. 
Ho 4: There is no significant difference between gender groups regarding support from partners and advisors

Ho 5: There is no significant difference between different age groups of business regarding support from partners and advisors

Ho 6: There is no significant difference between the different group sizes of employees of start-up entrepreneurs

Ho 7: There is no significant difference between the age groups of entrepreneurs regarding support from partners and advisors.

\section{LITERATURE REVIEW}

According to Mazzarol, Volery, Doss and Thein (1999:49), starting a business is not an event but a process, which may take many years to evolve and come to fruition. Entrepreneurial research has developed along two lines: (1) the personal characteristics or traits of the entrepreneur; and (2) the influence of social, cultural, political and economic contextual factors. Mazzarol et al. (1999:49) indicates that early research in entrepreneurship focused on the entrepreneur. It sought to determine what personality characteristics distinguished entrepreneurs from non-entrepreneurs and examined the influence of these characteristics on organisation formation rates. Factors identified are the need for achievement, risk-taking propensity, locus of control, tolerance of ambiguity and desire for personal control. Numerous other background factors related to individual personality, such as previous employment, family background, gender, education, ethnic membership and religion have also been researched. Altogether, the combination of psychological traits interacting with background factors makes some individuals more likely entrepreneurial candidates than others.

Mazzarol et al. (1999:50) also indicates in terms of the environmental factors the following: within the social environment the impact of networks and the support of socio-political elites along with cultural acceptance are particular important. The economic environment studies focus on capital availability, aggregate economic indicators, economic recessions and unemployment. The political environment concerns mainly the support of public or semi-public agencies. Infrastructure development encompasses numerous variables such as the education system, the nature of the local labour market, incubator organisation, information accessibility and availability of premises. The market emergence theory integrates both concepts of niche emergence and technological innovation.

Deakins and Freel (2003:224) divide the business start-up process into a number of stages (idea formulation, opportunity recognition, pre-start planning and preparation, entry and launce, and postentry development). Each stage will have a number of factors that will impinge on the process. These may either encourage further development or have a negative influence, perhaps causing the individual nascent entrepreneur to terminate the process. These factors will include the nature of the local government, culture, access to finance, local support networks, role models and enterprise support and encouragement.

Deakins and Freel (2003:228) indicates that role models remove one of the stumbling blocks in the process of new business creation - they help to identify with success and encourage the next step of developing the business idea and identifying the right opportunity. Such role models should not be too successful, though: potential nascent entrepreneurs need to be able to identify with them, were they came from and how they were successful, and more publications that help to identify entrepreneurs from many different ethnic and cultural backgrounds are needed as source material.

In the pre-start planning and preparation phase of the entrepreneurial process Deakins and Freel (2003:229) refer to research, obtaining information (to determine entry strategy), raising sufficient finance, and the role and influence of social capital as important factors that will lead to eventual successes of new business creation.

Social capital (experience and advice available from extended family and social networks) is of key importance in start-up and entrepreneurial development. Its role is complementary to that of sources of financial capital, yet it has received relatively limited attention in research with start-up and nascent entrepreneurs, although this is beginning to change. Davidson and Honig (2003) (in Deakins \& Freel, 2003:230) comments that from an entrepreneurial perspective, social capital 
provides networks that facilitate the discovery of opportunities, as well as the identification, collection and allocation of scarce resources. They indicate that sources of social capital are important for predicting start-up entrepreneurial activity.

Social capital replaces the role of institutional sources of advice in the same way that informal finance can replace and substitute for the role of institutional sources of formal finance.

Start-up and on-going small businesses face problems and challenges of different nature. According to Hamilton and Rivera (2003:6) across studies, it has been found that most start-ups face by large difficulties in raising capital, elevated costs of establishing location and infrastructure to establish their businesses and the groundwork for preparing objective and effective business plans. In the case of the younger entrepreneurs, their problems expand by their lack of experience, in addition to the same obstacles faced by experienced entrepreneurs. Meanwhile ongoing SMEs often lack resources to take care of opportunities, time to scan the environment and plan effectively as well as time management.

\section{Research Conducted in South Africa}

In South Africa no formal study has been conducted to analyse the influence of start-up factors on small businesses and entrepreneurial ventures. Most of the research conducted was to determine obstacles or barriers to start and grow a business.

A study in 2004 commissioned by Ernst and Young and Rand Merchant Bank (Naudé, 2004:10) to establish the factors that inhibit entrepreneurship in South Africa highlights the following factors: limited access to start-up capital, an appropriate education system, government regulations and bureaucracy, lack of business knowledge, costs of entry, discrimination, lack of mentorship and government assistance and uncompetitive behaviour from establish companies.

Co and Mitchell (2004) conducted a study in terms of a comparative analysis of perceived obstacles to entrepreneurship. This research delves into the South African entrepreneur's perceptions of policy obstacles in doing business. The perceived quality of government action in the different policy fields is the main thrust of their research. The main policy areas perceived as problematic were crime and theft, tax regulations and inflation.

In the research of Pretorius and Van Vuuren (2003), they addressed the contribution of support and incentive programs to entrepreneurial orientation and start-up culture in South Africa. This research investigated the proposition that the South African culture is conducive to entrepreneurial orientation.

Co (2003) did an analysis of the formal institutional factors affecting entrepreneurship in a developing country: lessons for Africa. The main aim of this research was to identify and review what the Government and support institutions are doing to facilitate and encourage entrepreneurship as well as to study the linkages between the different Government and nonGovernment agencies that support SMMEs.

Verhoeven and Smit (2001) did empirical research on the factors influencing profitable growth in small and medium-sized businesses. This research attempted to resolve the research question why some small and medium-sized business grow profitably and others not. They identified that three factors are mainly responsible for a profitable growth in small and medium-sized businesses: the opportunity, the entrepreneur and the resources. The small and medium-sized businesses experience resource problems and cash flow as the main problems that inhibit profitable growth in small and medium-sized business.

The research of Van Eeden, Viviers and Venter (2003) about a comparative study of selected problems encountered by small businesses in the Nelson Mandela, Cape Town and Egoli metropoles indicated that the macro-environment contains economic, socio-demographic, political, physical, international and technological factors, over which management has no control. According to this research the macro-environmental problems were identified as the most influential to the failure problems experienced by small businesses. Van Eeden et al. (2003:14) highlighted that 
South African entrepreneurs view economic uncertainty, crime, corporate tax rates and labour legislation, as the biggest threats facing the small business sector. Fluctuating and high interest and inflation rates result in higher costs to the small business, and hamper their ability to plan and budget effectively.

Kesper (2001) and Rogerson (2001) each did research on the growth of SMMEs in the manufacturing sector. Kesper found that poor macro-economic conditions and more pricecompetitive imports are indicated as reasons for poor performance. Rogerson focused only on the manufacturing SMMEs in the Gauteng province and indicated that there was a need for an improved support framework that would assist the manufacturing SMMEs to gear up to meet the demands of new international competition.

The South African government's support structures for SMMEs include the following:

The centre for Small Business Promotion, established by the Department of Trade and Industry (DTI) at national level is responsible for SMMEs policy-related matters and support programmes. The centre gave birth to Ntsika Enterprise Promotion Agency (which is now been replaced by the South African Enterprise Agency (SEDA) and Khula Enterprise Finance Limited. Khula Enterprises Finance Limited was established as an agency of the DTI. It is a wholesale financier who facilitates access to credit for SMMEs through various delivery mechanisms, including commercial banks, retail financial intermediaries and micro credit outlets. This financing assistance Khula provides includes loans and credit guarantees. SEDA is responsible for non-financial services like marketing, training programmes, procurement advice, and technology assistance and mentoring to businesses. Most of these services are rendered to SMMEs through services providers, e.g. Tender Advice Centres (TACs), Manufacturing Advisory Centres (MACs), Local Business Services Centres (LBSCs), Non-Governing Organizations (NGO) and Community Based Organisations (CBOs) (Ladzani, 2001)

\section{SMALL BUSINESSES IN SOUTH AFRICA}

According to the Ntsika Annual Review, SME's (Small and Medium Enterprises) form 97,5 percent of all businesses in South Africa. They generate 34,8 per cent of the gross domestic product (GDP), contribute to 42,7 per cent of the total value of salaries and wages paid in South Africa, and employ 54,5 per cent of all formal private sector employees (Diederichs, in Nieman, Hough \& Nieuwenhuizen, 2003:3).

The National Small Business Act 102 of 1996 (as emended) of South Africa offers an official definition of small businesses in South Africa. It covers all sectors of the economy as well as all types of enterprises and consists of two parts, namely qualitative and quantitative. In terms of the qualitative criteria, which relate to ownership structure of the business, it must be a separate and distinct business entity; cannot be part of a group of companies; must include subsidiaries and branches, if applicable, when measuring the size; should be managed by its owners; and can be a natural person, sole proprietorship, partnership or a legal person such as a close corporation or company.

The quantitative criteria classify businesses into micro, very small, small and medium using the following criteria in respect of different sectors of the economy: total full-time paid employees; total annual turnover and total gross asset value (excluding fixed property). Small businesses in South Africa refers to firms with 50 or fewer employees, while small business in Europe and the USA is seen as firms with 100 to 500 employees (Nieman, 2006:4-6).

The Small Business in South Africa Annual Review of 2004 stated that the formal small enterprise sector is concentrated in the financial and business services (44\%), trade (23\%) and manufacturing (12\%) sectors. The number of entrepreneurs in the formal sector grew from 506000 in 2003 to 545 000 in 2004, an increase of just under 40 000. Currently the unemployment rate in South Africa is $25.5 \%$ (Statistics, SA Labour force survey).

Against the background of this literature review and the stated hypothesis, the research methodology followed in this research is discussed next. 


\section{RESEARCH METHODOLOGY}

\section{Research Design}

An ex post facto, formal design was used as respondents were requested to indicate on a four-point scale, how important they deemed 37 items, in a structured personal interview. This questionnaire formed the basis of the personal interview.

\section{Data Collection}

Data was collected by means of personal interviews and a sample size of 312 elements is included in the research. It was expected that the entrepreneurs reflected back on their start-up days and respond to the 37 questions in that regard. The parameters of interest that were used were:

- Geographical location - Gauteng province

- Number of employees - 0 to 350

- Starting date - 1997

\section{Data Analysis}

Factor analysis was conducted to determine whether stable factor structures are underlying the items included in the measuring instrument and to determine the accuracy of measurement.

Analysis of Variance was conducted to identify whether any statistical significant differences exist in terms of the dependant variables and the derived factors (Independent Variables). The data analysis is concluded with Sheffe's paired comparison test to determine the direction of statistical differences

The findings and major implications of the findings from the research conducted will be presented in the following section.

\section{FINDINGS}

The following factors were derived from the analysis:

- Factor 1 - Personal Management and involvement

- Factor 2 - Role Models

- Factor 3 - Effective Time Management

- Factor 4-Support (Partners and advisors)

Firstly the findings regarding the factor analysis (table 1) and thereafter the findings of the ANOVA (table $2-8$ ) will be provided.

Table 1: Factor correlation for rotated factors

\begin{tabular}{|c|c|c|c|c|}
\hline Factor & Factor 1 & Factor 2 & Factor 3 & Factor 4 \\
\hline Factor 1 & 0.838 & & & \\
\hline Factor 2 & 0.274 & 0.752 & & \\
\hline Factor 3 & 0.308 & 0.184 & 0.717 & \\
\hline Factor 4 & 0.281 & 0.129 & 0.121 & 0.781 \\
\hline
\end{tabular}

Eigen values of all four factors are above 1,0 indicating that that the variance explained by each factor is satisfactory. Alpha values for each factor are as follows:

- Factor $1-0.744$

- Factor 2-0.759

- Factor 3-0.602

- Factor $4-0.646$ 
According to Cooper and Schindler (2006:530) alpha levels of 0.6 and higher are acceptable and therefore the researchers deem the measurement to be accurate.

Analysis of Variance was conducted to determine the statistical significant differences between the following variables of the entrepreneurs under study: Gender, Age of the entrepreneur, Number of employees and Age of business. The results relating to personal management are presented in table 2:

Table 2: ANOVA between gender groups regarding Personal Management

\begin{tabular}{|c|c|c|c|c|c|}
\hline $\begin{array}{c}\text { Variable: } \\
\text { Gender }\end{array}$ & Mean & $\begin{array}{c}\text { Standard } \\
\text { deviation }\end{array}$ & F-Value & p-value & Sheffe \\
\hline Male $(\mathrm{A})$ & 3.289 & 0.438 & 7.12 & $0.0081^{\star * *}$ & $\mathrm{~A}>\mathrm{B}$ \\
\hline Female $(\mathrm{B})$ & 3.121 & 0.585 & & & \\
\hline
\end{tabular}

The finding indicates that there is a significant difference between the opinions of males and females with the male respondents regarding personal management and involvement as of greater importance when they started their entrepreneurial careers. Accordingly null hypothesis 1 is rejected.

There are significant differences between the entrepreneurs that started their businesses in different periods of time. Table 3 presents the finding:

Table 3: ANOVA between different starting dates (age of business) regarding Personal Management

\begin{tabular}{|c|c|c|c|c|c|}
\hline $\begin{array}{c}\text { Variable: } \\
\text { Age of Business }\end{array}$ & Mean & $\begin{array}{c}\text { Standard } \\
\text { deviation }\end{array}$ & F- Value & p-value & Sheffe \\
\hline $1-5$ years $(A)$ & 3.319 & 0.448 & 4.64 & $0.0106^{* * *}$ & $\mathrm{~A}>\mathrm{C}$ \\
\hline $6-10$ years $(B)$ & 3.202 & 0.585 & & & \\
\hline $11+(\mathrm{C})$ & 3.119 & 0.430 & & & $\mathrm{C}<\mathrm{A}$ \\
\hline
\end{tabular}

The finding indicates that dedication to management personally is of a bigger concern to entrepreneurs that just started their businesses. As the business matures the entrepreneur starts to delegate and become an entrepreneurial manager rather than a start-up entrepreneur. Accordingly null hypothesis 2 is rejected.

No significant differences related to personal management were found regarding the age of the entrepreneurs and their number of employees.

Regarding the second variable role models no statistical significant differences were found between the groups. If the tendency as indicated by the means and standard deviations are taken into account, role models were deemed as very important for entrepreneurs when then started their businesses. Therefore it can be deduced that whether the age of business, gender, number of employees or age of the entrepreneur is compared that role models are seen as very important to all of them.

The third variable tested among the different groups is effective time management. The results of the ANOVA are presented in table 4:

Table 4: ANOVA between different age groups of entrepreneurs regarding effective time management

\begin{tabular}{|c|c|c|c|c|c|}
\hline $\begin{array}{c}\text { Variable: } \\
\text { Age of Entrepreneur }\end{array}$ & Mean & $\begin{array}{c}\text { Standard } \\
\text { deviation }\end{array}$ & F- Value & p-value & Sheffe \\
\hline $20-30$ years $(A)$ & 3.152 & 0.559 & 4.71 & $0.0099^{\star \star *}$ & $\mathrm{~A}>\mathrm{C}$ \\
\hline $31-44$ years $(B)$ & 2.814 & 0.484 & & & \\
\hline $45+(\mathrm{C})$ & 2.736 & 0.619 & & & $\mathrm{C}<\mathrm{A}$ \\
\hline
\end{tabular}


The finding indicates that younger entrepreneurs deem effective time management more important when they started their businesses than their senior counterparts. The researchers are of the opinion that this is maybe because of maturity on the side of the senior group. It is also suspected that the influence of the stage of the business life cycle influences the opinion as well. The other variables do not show any significant differences but once again all deemed effective time management of importance if the tendency of the means and small standard deviations were to be taken into account. Therefore null hypothesis 3 is rejected.

The analysis of variable 4, support (partners and advisors) presents a number of interesting findings. There are statistical significant differences between all variables as well as variance within the groups. These findings are presented in tables $5-8$ :

Table 5: ANOVA between gender groups regarding support (partners and advisors)

\begin{tabular}{|c|c|c|c|c|c|}
\hline $\begin{array}{c}\text { Variable: } \\
\text { Gender }\end{array}$ & Mean & $\begin{array}{c}\text { Standard } \\
\text { deviation }\end{array}$ & F- Value & p-value & Sheffe \\
\hline Male $(\mathrm{A})$ & 2.830 & 0.759 & 6.35 & $0.0124^{\star * *}$ & $\mathrm{~A}>\mathrm{B}$ \\
\hline Female $(\mathrm{B})$ & 2.617 & 0.809 & & & \\
\hline
\end{tabular}

The finding indicates that upon reflection male entrepreneurs are of the opinion that support was more important to them than female entrepreneurs. This is particularly interesting as networks, partners, advisors and other support are of great importance for all entrepreneurs when a business is started. It can only be speculated that female entrepreneurs work more independently at the beginning than their male counterparts. Accordingly null hypothesis 4 is rejected.

Table 6: ANOVA between different starting dates (age of business) regarding support (partners and advisors)

\begin{tabular}{|c|c|c|c|c|c|}
\hline $\begin{array}{c}\text { Variable: } \\
\text { Age of Business }\end{array}$ & Mean & $\begin{array}{c}\text { Standard } \\
\text { deviation }\end{array}$ & F- Value & p-value & Sheffe \\
\hline $1-5$ years $(A)$ & 2.900 & 0.674 & 7.56 & $0.0007^{\star * *}$ & $\mathrm{~A}>\mathrm{C}$ \\
\hline $6-10$ years $(\mathrm{B})$ & 2.750 & 0.829 & & & \\
\hline $11+(\mathrm{C})$ & 2.513 & 0.875 & & & $\mathrm{C}<\mathrm{A}$ \\
\hline
\end{tabular}

It is proven by this finding that businesses in their early stages of the business life cycle needs more support than their businesses in the maturity phase. A lesson to be taken from this is that start-up businesses must rely on support that they create themselves, as it is a critical element of success. Although the importance of support significantly decline as the years go by, the start-up entrepreneur cannot ignore the fact that support is playing a vital role towards the maturation of a business. Accordingly null hypothesis 5 is rejected.

Table 7: ANOVA between different size of employee groups of entrepreneurs regarding support (partners and advisors)

\begin{tabular}{|c|c|c|c|c|c|}
\hline $\begin{array}{c}\text { Variable: } \\
\text { Size of employee } \\
\text { groups }\end{array}$ & Mean & $\begin{array}{c}\text { Standard } \\
\text { deviation }\end{array}$ & F- Value & p-value & Sheffe \\
\hline $0-10$ years $(\mathrm{A})$ & 2.700 & 0.723 & 3.41 & $0.0348^{\star * *}$ & $\mathrm{~A}>\mathrm{C}$ \\
\hline $11-20$ years $(\mathrm{B})$ & 2.806 & 0.838 & & & \\
\hline $21+(\mathrm{C})$ & 3.011 & 0.872 & & & $\mathrm{C}<\mathrm{A}$ \\
\hline
\end{tabular}

This finding supports the finding regarding the age of an entrepreneurial concern. In reflection entrepreneurs that have grown their businesses since start-up to a true entrepreneurial concern indicate that support from partners and advisors are very important. If the mean and standard deviation of the group with $11-20$ employees are taken into consideration it can be observed that there are only a slight difference between the group with $0-10$ employees which is also significant. Therefore null hypothesis 6 is rejected. 
Table 8: ANOVA between different age groups of entrepreneurs regarding support (partners and advisors)

\begin{tabular}{|c|c|c|c|c|c|}
\hline $\begin{array}{c}\text { Variable: } \\
\text { Age of Entrepreneur }\end{array}$ & Mean & $\begin{array}{c}\text { Standard } \\
\text { deviation }\end{array}$ & F- Value & p-value & Sheffe \\
\hline $20-30$ years $(\mathrm{A})$ & 3.300 & 0.429 & 4.07 & $0.0183^{* * *}$ & $\mathrm{~A}>\mathrm{B}$ \\
\hline $31-44$ years $(\mathrm{B})$ & 2.753 & 0.763 & & & $\mathrm{~B}>\mathrm{C}$ \\
\hline $45+(\mathrm{C})$ & 2.710 & 0.811 & & & $\mathrm{~A}>\mathrm{C}$ \\
\hline
\end{tabular}

In their reflection back to start-up days of the business, the older entrepreneurs indicated that support was not that important to them. This is only natural as one tends to forget the role players that made a real contribution at business start-up. They are now entrepreneurial managers, in many cases corporate entrepreneurs. The young and younger entrepreneurs clearly indicate that support played a big role in their start-up as they are making use of those support structures at the moment to be successful. Accordingly, null hypothesis 7 is rejected.

\section{IMPLICATION OF FINDINGS}

In terms of the findings stated in the previous section, the major implications of these findings for South Africa are as follow:

- Although operating in the same environment, differences exist in needs and factors influencing male and women entrepreneurs, age of the entrepreneur and the stage of the business life cycle. This implies that existing government and private support structures and education and training programmes must make provision for these differences in their various offerings.

- Potential entrepreneurs must be made aware of the role that personal management and involvement, role models, effective time management and support from partners and advisors will play in the success of their business.

- In South Africa, little attention is given to role models and success stories of entrepreneurs and small businesses. The focus is more on failures. The importance and recognition of role models must receive more attention and be included in training and education programmes.

- The research indicated that entrepreneurs do not regard support as the business matures as important. This has a major implication on the survival of businesses because, during the maturity phase, support and advice is much needed.

\section{CONCLUSION AND RECOMMENDATIONS}

The research conducted to determine the influence of start-up factors in small businesses and entrepreneurial ventures in South Africa found four broad categories of start-up factors. These factors are: personal management and involvement; role models; effective time management; and support from partners and advisors. The findings of this research are in line with similar international research (Mazzarol et al., 1999 and Deakins \& Freel; 2003) on various aspects influencing the startup of businesses. It is very clear that there is a definite difference in the needs and factors influencing: women and male entrepreneurs; the age of entrepreneurs; and the stage of the business in its life cycle. Although a lot of support, education and training are given in South Africa, policy makers and educational institutions should take note of the various differences in needs and make provision in their support and training for these differences. It is also recommended that existing small business owners and entrepreneurs must create their own support structure specifically when they move from the start-up stage to the new firm stage, as this is a stage where support and advice is much needed.

\section{REFERENCES}

Atherton A. 2003. Preparing for entrepreneurship - an examination of the "pre-start" phase of business creation, paper delivered at the 2003 ICSB conference, Belfast Ireland. 
Co MJ. 2003. An analysis of the formal institutional factors affecting entrepreneurship in a developing country: lessons for Africa. The Small Business Monitor, 1(1):96-102.

Co MJ, Groenewald J, Mitchell B, Nayager T, Van Zyl J, Visser K, Train W \& Emanual B. 2006. Entrepreneurship. Fresh perspectives. Cape Town: Pearson Education South Africa.

Co MJ \& Mitchell B. 2004. Comparative analysis of perceived policy obstacles to entrepreneurship. Conference proceedings of the $16^{\text {th }}$ Southern African Institute for Management Scientists conference held in Potchefstroom.

Cooper DR \& Schindler PS. 2006. Business Research Methods. $9^{\text {th }}$ ed. New York: McGraw-Hill.

Deakins D \& Freel M. 2003. Entrepreneurship and small firms. $4^{\text {th }}$ ed. Berkshire: McGraw-Hill.

Hamilton LC \& Rivera LE. 2003. Is there potential to stimulating start-ups and strengthen SMEs competitiveness? Paper delivered at the 2003 ICSB conference, Belfast Ireland.

Kesper A. 2001. Failing or not aiming to grow? Manufacturing SMMEs and their contribution to employment growth in South Africa. Urban Forum, 12(2):171-203.

Ladzani W. 2001. Small business development in South Africa under the majority rule. Conference proceedings of the $14^{\text {th }}$ annual conference of Small Enterprise Association of Australia and New Zealand (SEAANZ) held in Wellington, New Zealand.

Maas G \& Herrington M. 2006. Global Entrepreneurship Monitor: South African Report 2006. The UCT Centre for Innovation and Entrepreneurship.

Mazzarol T, Volery T, Doss N \& Thein V. 1999. Factors influencing small business start-ups. A comparison with previous research, International Journal of Entrepreneurial Behaviour and Research, 5(2):48-63.

Naudé C. 2004. Wat SA se top entrepreneurs gemeen het. Finansies en Tegniek. 7 April:10-12.

Nieman G ed. 2006. Small Business Management, a South African approach. Pretoria: Van Schaik.

Nieman G. 2001. Training entrepreneurs and small business enterprises in South Africa: a situational analysis, Education and Training, 43(8/9):445-450.

Nieman G, Hough J \& Nieuwenhuizen C. 2003. Entrepreneurship: a South African perspective. Pretoria: Van Schaik

Pretorius M \& Van Vuuren JJ. 2003. Contribution of support and incentive programs to entrepreneurial orientation and start-up culture in South Africa. South African Journal of Economic and Management Sciences, 3:514 - 528.

Rogerson CM. 2001. Growing the SMME manufacturing economy of South Africa: evidence from Gauteng Province. Journal of Contemporary African Studies, 19(2):267-291.

South Africa. Department of Trade and Industry. 2004. Annual Review of Small Business in South Africa - 2004. Pretoria: Government Printer.

Statistics South Africa. 2006. Statistical Release P0210, Labour Force Survey March 2006.

Van Eeden S, Viviers S \& Venter D. 2003. A comparative study of selected problems encountered by small businesses in the Nelson Mandela, Cape Town and Egoli metropoles. Management Dynamics, 12(3):13-23.

Verhoeven CE, Crous MJ \& Smith AVA. 2001. Faktore wat winsgewende groei in klein en mediumgrootte sakeondernemings beïnvloed. Tydskrif vir Geesteswetenskappe, 41(1):41-52. 
Von Broembsen M, Wood E \& Herrington M. 2005. Global Entrepreneurship Monitor: South African Report. Cape Town: Graduate School of Business, University of Cape Town.

Walker EA \& Webster BJ. 2007. Gender, age and self-employment: some things change, some stay the same. Women in Management Review, 22(2):122-135. 